\title{
The Role Of Notary In The Implementation Of Credit Agreement And The Default Settlement With Mortgage Right Warranty (A Study At Bank In Pekalongan)
}

\author{
Mochammad Lukman ${ }^{1}$, Atik Noer Chalimah ${ }^{2}$ and Gunarto ${ }^{3}$
}

Abstract. Notary is required in a credit agreement which is performed by the bank and its debtor. Problems studied in this research was about the role of Notary in the implementation of Credit Agreement, the factors causing the occurrence of defaults with the guarantee of Mortgage Rights and efforts to settle default disputes with Mortgage Right loan agreement. The method used in this research was with the sociological juridical approach, it was sourced from collecting data obtained from the primary and secondary data, then the data were analyzed by qualitative analysis method. The result of the research are the role of a Notary in the implementation of Credit Agreement is to make the credit agreement requested by the creditor, responsible for the credit document made, and the Notary in charge and responsible to provide guidance and advice to the bank related to the credit documents. Regarding factors causing default with guarantee of Mortgage Rights and settlement of loan defaults is caused by several factors such as internal factor of bank, customer factor and external factor of bank and debtor. The settlement of default is done in 2 options, that is in litigation and non-litigation settlement.

Keywords: Credit Agreement; Default; Guarantee; Mortgage Rights.

\section{Introduction}

A notary plays an important role to help create legal certainty and protection for the community. Notary's role in preventing the occurrence of legal matters is through the authentic deed he makes as the most perfect evidence in court. This is in contrast to the role of an advocate, in which the advocate profession places more emphasis on the defense of one's rights when a difficulty arises. On the other hand, the notary profession must play a role to prevent early difficulties in the future. 4

Notary PPAT (Land Deed Official) shall cooperate (mutually assist and equip) with the bank to issue a notarial deed of PPAT which is required in a credit agreement. This agreement will be done by bank with its debtor including credit agreement with mortgage guarantee. The Mortgage Right Agreement is created by registration. According to Article 1 point (5) of the Mortgage Rights Act, it states that: "Deed of

${ }^{1}$ Students of Master of Notary Law, Faculty of Law, Universitas Islam Sultan Agung email mochammad.sungkar@yahoo.com

2 Students of Master of Law, Faculty of Law, Universitas Islam Sultan Agung email atikhazan@yahoo.co.id

3 Profesor of Faculty of Law UNISSULA

4 Tan Thong Kie 2007 Studi Notariat Serba Serbi Praktek Notaris Ichtiar Baru van Hoeve Jakarta p.102 
Mortgage Right is a PPAT deed containing the Mortgage Rights to certain creditor as Security for debt repayment."

The purpose of the registration is to fulfill the principle of publicity as well as a guarantee of certainty to the creditor regarding objects that have been burdened by mortgage right. The existence of the rule of law concerning the implementation of the imposition of Mortgage Rights in a credit agreement aims to provide legal certainty and protection for all parties in utilizing the land and the objects related to the land as collateral for credit. Basically, a credit agreement is made to assist the debtor/ prospective debtor in obtaining a credit loan from a banking institution or non-bank financial institution. It is done by binding the principal agreement and the accesoir agreement, it can be said that the principal agreement from the credit agreement and the accesoir agreement is the mortgage right. Prior to the credit agreement is made, the bank will conduct a preliminary examination to see if the guaranteed item is free from problems and can be used as a guaranteed object of the agreement. Although the bank has done it, but it still found problems in the credit agreement. The problem in question is the constraints derived from a credit agreement implementation. The existence of default credit is due to the fact that the debtor does not do what should be done according to the terms of the credit agreement as in the case of delay in loan repayment.

In line with the statement, the focus of the study aims to examine and to analyze the role of Notary in the implementation of credit agreements up to efforts to solve problems that arise in the credit.

\section{Research Methods}

This research is a sociological juridical approach. The sociological juridical approach is used to analyze the various laws and regulations of credit agreements with mortgage liability. Meanwhile, socio legal research approach is a study that refers to the norms and legal principles contained in the legislation and court decision/fact in the field. According to F.X. Adji Samekto, Social legal studies conceptualize law as the norm and simultaneously as reality. ${ }^{5}$

\section{Result And Discussion}

\subsection{Notary's Role in the Implementation of Credit Agreement with Mortgage Right Guarantee}

Notary is a public official authorized to make an authentic deed as long as the making of certain authentic deeds is not reserved for other general officials. The making of an authentic deed is required by law and regulation in order to create certainty, order and legal protection. In addition to the authentic deeds made by or in the presence of a

\footnotetext{
${ }^{5}$ Anis Mashdurohatun, Redyanto Sidji, Gunarto and Mahmutarom, Factors Causing Banking Cyber Crime in Indonesian, International Journal of Economic Research, Volume 14 Number 15 2017, p.295
} 
Notary, it is not only because required by legislation, but also because it is desired by the parties concerned to ensure the rights and obligations of the parties for the sake of certainty, order and legal protection for the interested parties at once, for society as a whole. Not unlike the Notary, PPAT (Land Deed Official) also has an important role in the implementation of land administration of land registration data. According to Government Regulation No. 24 of 1997 concerning Land Registration, the transfer and imposition of land rights can only be registered if proven by the PPAT Deed.

Basically, a credit agreement is made to assist the debtor in obtaining a credit loan from a banking institution by binding the principal agreement with the accesoir agreement. The principal agreement from the credit agreement and the accesoir agreement is the Mortgage Rights. ${ }^{6}$

Notary's role in the crediting system by the banks is to provide legal certainty to both parties who enter into credit agreement. In addition, the role of Notary PPAT also as the authorized party to check the guarantee goods in the form of Mortgage Rights to ascertain whether the guarantee is legitimate before the law or not. It is done to avoid if there is a possibility of Mortgage Right objects still include in legal dispute. A certified deed or warmerking and checked by a notary is a matter to undertake to mitigate negative factors, such as the achievements given in the form of money, goods and services provided by the bank are absolutely guaranteed the validity. Further, it also facilitates the bank to execute the collateral if in the future the Debtor has an injury or other legal issue arises. ${ }^{7}$

\subsection{Factors Cause Occurrence of Default With Deposit Guarantee}

The accomplishment of achievement is the core point of the engagement as defined in article 1234 of the Civil Code which reads: "Each engagement is to give something, to do something, or to do nothing." The debtor cannot fulfill his obligation to the creditor is due to two possibilities reasons, firstly, due to the debtor's mistake, either intentionally not fulfilling obligations or due to negligence. Secondly, because circumstances force (overmarch) beyond the ability of the debtor, the debtor is not guilty. In the event that the debtor cannot fulfill the achievement and there is something wrong with him, then it can be said that the debtor is in a state of default.

There are four forms of default: ${ }^{8}$

- Not performing what he undertakes to do;

- Implementing what is promised, but not as promised;

- Do what is promised but too late;

- Do something that according to the agreement should not be done.

\footnotetext{
${ }^{6}$ Direct interview with PPAT Dwi Jati Pratiwi SH. M.Kn on 16 March 2018

${ }^{7}$ Direct interview with PPAT Riza Sungkar,SH. on 14 March 2018

${ }^{8}$ R.Subekti 1970 Hukum Perjanjian Second Editing Pembimbing Masa Jakarta p. 50
} 
Associated with the form of default, according to Subekti, there are 4 legal consequences of a debtor:

- Pays for losses suffered by creditors or pay the compensation;

- Cancellation agreement or also called the breaking of the agreement

- Risk transition;

- Pay the cost of the case, if this dispute is sent before the judge.

Negligence of the debtor in fulfilling its obligation is very detrimental to the bank as its creditor. The state of the debtor that cannot pay off the credit as promised can be called bad credit. Bad credit is caused by one or several factors that the bank must recognize early on. This is due to the weakness of internal bank, the debtor (customer) and external. ${ }^{9}$

In principle, the case of bad credit/default is a civil matter which according to the civil law terminology, the relationship between the debtor and the creditor (bank) is a debts and receivables relation. This relationship appears from the agreement. The debtor pledges to return the loan along with the fees and interest, and the creditor gives the credit. In the event that the credit provided categorized as bad credit, the detection of bad debts can be done systematically by developing a 'self-introduction' system. It is a list of events or symptoms that are expected to cause a loan to develop into bad credit. Credit settlement is a termination of the relationship between the bank and the debtor.

\subsection{Effort to the Default Dispute Settlement In Mortgage Rights Credit Agreement}

Credit settlement is a termination of the relationship between the bank and the debtor. This is the final step because if this relationship continues it will result in greater losses for the bank, as well as impact on the non-fulfillment of legal protection against the Bank.

In the context of the settlement of default, it can be done in 2 ways, namely: ${ }^{10}$

- Litigation Settlement

Settlement of bad credit through legal channels or assistance from third parties is made when the debtor is uncooperative to settle the obligations. The way of settlement of bad loans by using a legal approach that exists in banking practice. It is the Settlement of Credit through the District Court.

- Non-Litigation Settlement

Speaking of non-litigation settlements, there is actually an alternative dispute settlement institution which is a dispute resolution or disagreement institution through a procedure agreed upon by the parties, namely non-court settlement in consultation, negotiation, mediation, conciliation or expert judgment (Article 1

\footnotetext{
${ }^{9}$ Direct interview with PPAT Riza Sungkar,SH. on 14 March 2018

${ }^{10}$ Direct interview with PPAT Riza Sungkar,SH. on 14 March 2018
} 
number 10 of Act No. 30 of 1999 on Arbitration and Alternative Dispute Resolution). Another definition of Alternative dispute settlement is the settlement of disputes through non-court lines. It is generally taken by means of negotiations led or initiated by neutral or impartial third parties. Alternative dispute settlement conducted out of court and its implementation is left entirely to the parties and the parties may choose to settle the dispute which will be pursued through consultation, negotiation, mediation, conciliation, arbitration or requesting expert judgment. This becomes the full free will of the parties. The parties have the freedom to choose the form of dispute resolution. This is the difference between settlement which is done though the court and not. Dispute settlement through alternative dispute resolution is still considered to be relatively cheap and fast, therefore the current use of noncourt settlement methods is more favorable than court settlement.

In this case, the implementation of a peaceful credit settlement is a priority because: ${ }^{11}$

- Delinquent arrears of interest and/or maximum fine of interest and/or penalty not paid by the debtor.

- The sale of part or all of the collateral is under the control of the debtor or the owner of the collateral for the installment or settlement of the debtor's liability.

- Transferring of the debtor's assets by the Bank for the installment or settlement of the debtor's liabilities.

\section{Closing}

\subsection{Conclusion}

Notary's role in the implementation of Credit Agreement is to make the credit agreement deed required by the creditor, responsible for the credit documents he makes. The Notary is in charge and responsible to provide guidance, and advice to the bank in relation to the credit documents. Regarding factors causing default with guarantee of Mortgage Rights and settlement of loan defaults in the Mortgage Credit Agreement is caused by several factors such as internal factor of bank, customer factor and external factor of bank and debtor, while settlement of default is done with 2 options, that is litigation and non-litigation settlement.

\subsection{Suggestion}

Notary and PPAT (Land Deed Official), they should pay more attention to the principle of proportionality and prudential in mortgage credit agreements involving banks and debtors to minimize unequal position in the bank credit agreement.

${ }^{11}$ Direct interview with PPAT Riza Sungkar,SH. on 14 March 2018 


\section{JURNAL AKTA}

\section{References}

[1] Anis Mashdurohatun, Redyanto Sidji, Gunarto and Mahmutarom, Factors Causing Banking Cyber Crime in Indonesian, International Journal of Economic Research, Volume 14 Number 152017

[2] R.Subekti 1970 Hukum Perjanjian Second Editing Pembimbing Masa Jakarta.

[3] Tan Thong Kie 2007 Studi Notariat Serba Serbi Praktek Notaris Ichtiar Baru van Hoeve Jakarta.

[4] The Civil Code

[5] The Mortgage Rights Act

[6] Government Regulation No. 24 of 1997 concerning Land Registration 